\title{
SUSTAINABILITY AND DETERMINANTS OF ITALIAN PUBLIC DEFICITS BEFORE AND AFTER MAASTRICHT
}

\author{
EMMA GALLI \\ FABIO PADOVANO
}

CESIFO WORKING PAPER NO. 1391

CATEgory 2: Public ChOice

JANUARY 2005 


\title{
SUSTAINABILITY AND DETERMINANTS OF ITALIAN PUBLIC DEFICITS BEFORE AND AFTER MAASTRICHT
}

\begin{abstract}
This paper has two goals. 1) To evaluate the sustainability of Italian public deficits according to the methodology developed by Trehan and Walsh $(1988,1991)$ and Bohn (2004); 2) To analyze how the determinants of debt creation evolved in the years following the Maastricht Treaty and how this evolution shaped the development of the Italian public finances. The analysis is carried out in three steps; first we estimate and compare the stochastic properties of the main indicators of the Italian budget performance to test for sustainability; second, we confront the results of a cointegration-vector error correction model on two sample periods: a "pre Maastricht" (1950-1991) and a "post Maastricht" (1950-2002), to identify the main determinants of public deficits, according to the theoretical literature and the dynamic relationship between each of them and the dependent variable; third, we use the results of these estimates to specify a dummy variable model that evaluates how Italian fiscal policy reacted to changes in these determinants in the 1950-2002 sample. We conclude that a) In this period Italian public finances failed the sustainability test; b) Debt creation is much more sensitive now than before 1991 to external constraints, chiefly the numerical rules imposed by the Maastricht Treaty itself, institutional factors, such as the budget approval rules and the relative political power of the Minister for the Economy.
\end{abstract}

JEL Code: H62, E62.

Keywords: public deficits, Maastricht Treaty, comparative test, cointegration.

Emma Galli

University of Rome "La Sapienza"

Faculty of Political Science

P. le Aldo Moro 5

00185 Rome

Italy

emmagalli@hotmail.com
Fabio Padovano

University of Rome Tre

Center for Research on the Economics of

Institutions

Via Corrado Segre 4

000146 Rome

Italy

padovano@uniroma3.it

Paper presented at the Scientific Meeting of the Società Italiana di Economia Pubblica, Pavia, October 4-5, 2004 and at the CESifo - LBI Conference on "Sustainability of Public Debt" Munich, October 22-23, 2004. We thank the participants to these conferences and especially Reinhard Neck, Ian-Egbert Sturm and Massimo Bordignon for useful comments on a previous version of this paper. The usual caveat applies. 


\section{Introduction}

Article 1 of the Italian Constitution reads: "Italy is Democratic Republic based on labour". A more accurate description of the country's fiscal history would be "Italy is a Democratic Republic based on public debt". Out of its now 155 years long life as a unified country, only for less than 30 Italy had a debt-to-GDP ratio below $60 \%$.

In 1861, one of the first policy decisions of the newly unified state was to endorse the public debt of the pre-unitary states. This enabled the new Kingdom of Italy to begin its financial life with a debt-to-GDP ratio that was already above $100 \%$ in 1871 and continued to fluctuate within the $100-150 \%$ range until World War I. At the beginning of the Fascist regime (1922) the debt to GDP ratio was $128 \%$, touched a minimum of $80 \%$ in 1928 , only to grow again to a hefty $122 \%$ in 1938 , the last non-war year. In 1948, when the Republican Constitution was promulgated, the debt to GDP ratio was down to $39 \%$, mainly because of the hyperinflation in the aftermath of WWII, and remained below $60 \%$ until 1974. Since then it was a continuous rise, which resulted in the attainment of the one to one ratio again in 1990 and of a maximum of $126 \%$ in 1994. Since then the Maastricht Treaty brought some fiscal discipline, but the one to one ratio has yet to be broken down ${ }^{1}$.

Such a tormented financial history, together with the international obligations that Italy has endorsed by signing the Maastricht Treaty, call for a verification of the sustainability of the Italian public finances. The first task of this paper is thus performing a Trehan and Walsh $(1988,1991)$ sustainability test of the Italian public finances in the post-World War II period. Yet theses tests can indicate the presence, or the absence, of "forces" that eventually re-establish the equilibrium in the fiscal choices of a country; the identification of such forces, whose behaviour is ultimately responsible for the dynamics and sustainability of the fiscal policies, largely lies beyond the explanatory power of these methodologies. Hence, the second task of this paper is to analyse the determinants of the evolution of Italian public deficits. To this end, we resort to the theoretical literature on debt creation and to other econometric tests of hypotheses. This literature provides several alternative explanations of why decision-makers choose debt instead of taxes to finance public expenditures. To identify which of these factors played the most important role in the development of the Italian public finances, we divide the analysis in two steps. First, we specify and estimate a cointegration-vector error correction model of the determinants of the deficit in the post WWII period. Not only this methodology is in line with Trehan-Walsh tests, being based on stationarity analysis, too, but it allows to evaluate and compare, in a single theoretical structure, the relative explanatory power of the alternative theories of debt creation. Most of all, the estimation of

\footnotetext{
${ }^{1}$ Data on the debt-to-GDP ratio are taken from Fratianni and Spinelli (1991).
} 
this model on two sample periods, a "pre Maastricht" (1950-1991) and a "post Maastricht" (19502002), offers a preliminary evidence of whether the constraints imposed by the Maastricht Treaty affected both the deficit level and its determinants. This preliminary evidence is used in the second step of the analysis as the basis for the specification of a dummy variable model, which evaluates how Italian fiscal policy reacted to structural changes in the most important determinants during the 1950-2002 time interval, Maastricht criteria included.

Two are the main conclusions of these analyses. First, and predictably, in the period under consideration Italian public finances fail the sustainability tests. Second, with respect to the pre1991 period, now debt creation appears much more sensitive to external constraints, chiefly the numerical rules imposed by the Maastricht Treaty itself, and to institutional factors, such as the budget approbation rules and the relative political power of the Minister for the Economy. Other economic and political factors seem to have played a less important role.

The rest of the paper is organized as follows. Section 2 illustrates the evolution of the fiscal variables in the sample period under investigation, 1950-2002, presents the test of the sustainability of these variables and discusses the results. In section 3 we turn to the analysis of the determinants of the fiscal policy variables, chiefly the public deficit, with section 4 surveying the competing theories of debt creation to be tested and compared. Section 5 describes the specification of the vector-error correction model and discusses the results emerged from the estimates on the "preMaastricht" sample (1950-1991) and a "post-Maastricht" (1950-2002) sample. In section 6 we highlight the main changes in the determinants of public deficit in Italy emerged from the estimation of the VEC model on the two samples and estimate the dummy variable model, which assesses how the changes in these determinants, including the provisions of the Maastricht Treaty, affected the Italian fiscal policy. Section 7 reassumes the main findings of the analysis.

\section{Evolution and sustainability of fiscal variables}

Figures 1 and 2 report the evolution of the GDP ratios of the main fiscal indicators (total and primary surplus, public debt and total interest outlays), while figure 3 illustrates the public expenditures and revenues of the general government in real terms from 1951 to 2003. All variables appear stable at moderate levels until the early 1960s; the mid-1960 marked the beginning of a period of increasing fiscal imbalances that tapered off around 1994, as the deadline for joining the European Monetary Union (may 1997) was approaching. A comparison of figure 3 with figure 1 and 2 (as well as of the original series) shows that fiscal disequilibria are not the product of the dynamics of GDP. If anything, the nominal debt is greater than the real debt and its GDP ratio, since the 1970s and 1980s saw increasing and high levels of inflation, while in the 1990s and 2000s 
inflation steadily declined and is now below the EU average. The evolution of the Italian public finances thus provides a quite interesting sample for sustainability analysis.

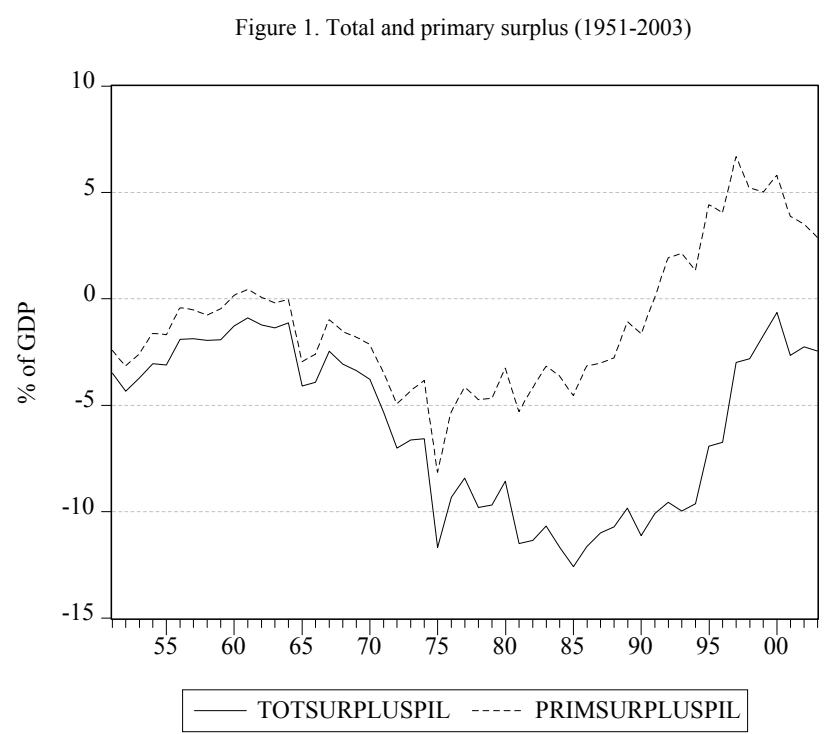

Figure 2. Public Debt and Interest Outlays (1951-2003)

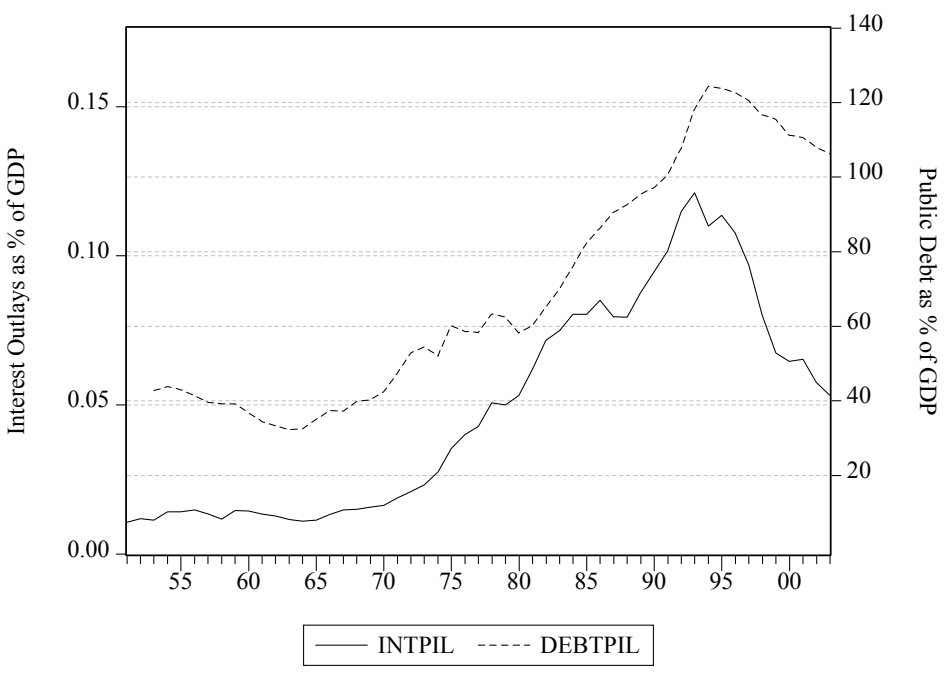

Figure 3. Real total expenditures and revenues. General government (1951-2003)

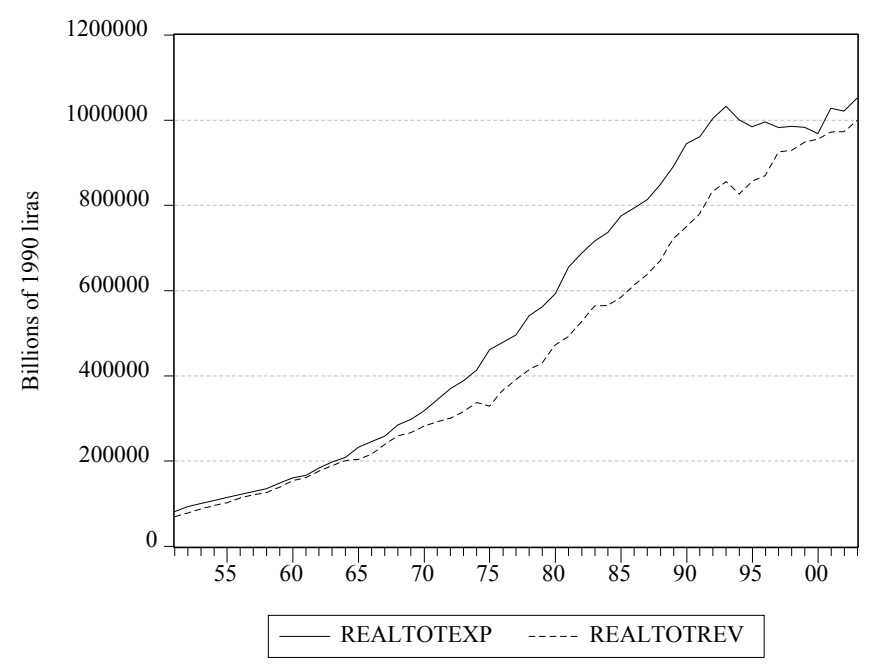


To this end, we follow the methodology developed by Trehan and Walsh $(1988,1991)$ and described by Bohn (2004) based on the idea of "ad hoc sustainability". This approach assesses the sustainability of particular fiscal policies by verifying whether it is on a trajectory path such that the expected present value of future primary surpluses equals the initial debt. Examining the unit roots and/or cointegration properties of fiscal data can test the satisfaction of the intertemporal budget constraint implied by this condition. In particular, Trehan and Walsh (1988) show that if real revenues, real public expenditures and real debt have unit roots, a stationary with interest deficit is sufficient to satisfy the ad hoc sustainability condition. Equivalent statements (as demonstrated by Bohn, 2004), based on budget identifies with fixed interest rate $r$, are that the primary surplus and debt are cointegrated with a cointegrating vector $(1,-r)$; or that revenues, non-interest outlays and debt are cointegrated with vector $(1,-1,-r)$. We use the original Trehan and Walsh (1988) methodology, as the examination of the stochastic properties of the series is also required by the cointegration-vector error correction analysis of the determinants of fiscal choices.

Table 1 reports the results of the Augmented Dickey Fuller (ADF) and Phillips-Perron (PP) tests of the null hypothesis of a unit root against the trend-stationary alternative. The fiscal variables under test are public debt, primary deficit, total deficit, total revenues, total outlays, non-interest and interest outlays. All series present a unit root, including the primary deficit; this implies that the Trehan and Walsh (1988) sustainability condition is not satisfied in the Italian case. Interestingly, the results are also logically consistent, since the with interest deficit, which is a linear function of the primary deficit and public debt, is non-stationary, just like its components. This is a further condition of the Trehan-Walsh test, which is often violated, as in the case of the U.S. sample (Bohn, 2004).

The real time series however suffer from a noticeable non-stationarity in variances. Table 2 illustrate the problem by reporting the standard deviation of primary deficit, total deficit and public debt for the 1951-1975 and 1976-2003 subsamples. The standard deviations of the 1976-2003 variables exceed those of the 1951-1975 subsample by a factor that varies from about 2 to about 13 . Such unequal variances cast some doubts on the unit root results, for the technical reason that they imply that the OLS estimates underlying the unit root tests essentially disregard most of the sample; namely, all but the most recent and, in our case, more volatile observations. Table 2 also documents that the standard deviations of GDP ratios display greater growth over time than real variables, suggesting that the rising variances of the real fiscal variables are largely due to a slowdown of the growth of the economy.

To shed light on these doubts, we repeat the Trehan-Walsh sustainability test on the same variables of Table 1 normalized by GDP; Table 3 reports the results. Again for no series 
nonstationarity can be rejected; this corroborates the interpretation of lack of sustainability of the Italian fiscal policies derived from the stochastic properties of the real variables ${ }^{2}$.

In summary, the Trehan-Walsh tests yield three main results. First, real raw data provide more credible information about fiscal series than GDP ratios. Second, there is evidence that the relationship between debt and deficits involves a unit root. Third, since primary deficit is not found stationary, neither in real terms nor when scaled by GDP, one cannot conclude that revenues and outlays are cointegrated with vector $(1,-1)$. Italian fiscal policies are thus not ad hoc sustainable in the sample period under consideration.

\section{An overview of the evolution of the main determinants of the Italian public deficit}

Rejecting fiscal sustainability naturally leads to questioning what are the determinants of the evolution of the Italian fiscal variables and why these determinants place fiscal policies on an unsustainable path.

The theoretical literature on debt creation point at factors such as the deviation of economic indicators (like output, public expenditures and unemployment levels) from their usual dynamics, the internal cohesion governments facing adverse fiscal shocks, the struggles between spending and finance ministers within the cabinet, the binding force of the budget approbation procedures, the demands for intra and intergenerational redistribution triggered by demographic developments, and the participation to international agreements that constrain the country's monetary and fiscal policies (Alesina and Perotti, 1999).

${ }^{2}$ Scaling by GDP may raise questions about the stationarity of GDP itself. In the Italian sample under consideration, a unit root is not rejected at the $1 \%$ level in neither the whole time interval, nor in the 1951-1975 and 1976-2003 subsamples. 
Table 1. Unit Root Tests for Real Fiscal Variables

\begin{tabular}{|c|c|c|c|c|c|c|c|c|c|}
\hline \multirow{2}{*}{$\begin{array}{l}\text { Sanple period } \\
\text { Variable }\end{array}$} & \multicolumn{3}{|c|}{$1951-2002$} & \multicolumn{3}{|c|}{$1951-1975$} & \multicolumn{3}{|c|}{$1976-2003$} \\
\hline & $\mathrm{ADF}(4)$ & $\mathrm{PP}(12)$ & Verdict & $\mathrm{ADF}(2)$ & $\mathrm{PP}(6)$ & Verdict & $\operatorname{ADF}(2)$ & $\mathrm{PP}(6)$ & Verdict \\
\hline Public Debt & $-2.478^{* *}$ & $-1.708^{* *}$ & Unit Root & $0.213^{* *}$ & $-0.440^{* *}$ & Unit Root & $-1.892^{* *}$ & $-0.757^{* *}$ & Unit Root \\
\hline Primary Surplus & $-2.442^{* *}$ & $-1.543^{* *}$ & Unit Root & $1.236^{* *}$ & $3.219^{* *}$ & Unit Root & $-1.608^{* *}$ & $-1.933^{* *}$ & Unit Roo \\
\hline Total Surplus & $-2.263^{* *}$ & $-0.954^{* *}$ & Unit Root & $2.141^{* *}$ & $3.065^{* *}$ & Unit Root & $-1.116^{* *}$ & $-1.357^{* *}$ & Unit Roo \\
\hline Total Revenues & $-2.074^{* *}$ & $-2.045^{* *}$ & Unit Root & $-2.308^{* *}$ & $-2.303^{* *}$ & Unit Root & $-1.085^{* *}$ & $-1.349^{* *}$ & Unit Roo \\
\hline Total Outlays & $-2.513^{* *}$ & $-2.011^{* *}$ & Unit Root & $1.739^{* *}$ & $3.499^{*}$ & Unit Root & $-0.738^{* *}$ & $-0.870^{* *}$ & Unit Roo \\
\hline Non-Interest & $-2.724^{* *}$ & $-2.293^{* *}$ & Unit Root & $-0.690^{* *}$ & $1.929^{* *}$ & Unit Root & $-1.397^{* *}$ & $-1.638^{* *}$ & Unit Root \\
\hline Outlays & & & & & & & & & \\
\hline Interest Outlays & $-2.153^{* *}$ & $-1.575^{* *}$ & Unit Root & $3.106^{* *}$ & 7.145 & Conflict & -0.290 & 0.023 & Unit Roo \\
\hline Critical values $1 \%$ & -4.158 & -4.142 & & -4.158 & -4.394 & & -4.322 & -4.394 & \\
\hline Critical values $5 \%$ & -3.504 & -3.496 & & -3.659 & -3.612 & & -3.579 & -3.612 & \\
\hline
\end{tabular}

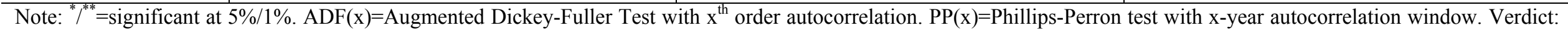
Unit root if ADF and PP fail to reject; stationary if ADF or PP reject.

Table 2. Standard Deviations of Fiscal Variables

\begin{tabular}{lrrr}
\hline Variable & \multicolumn{1}{c}{$1951-75$} & \multicolumn{1}{c}{$1976-2003$} & \multicolumn{1}{c}{ Ratio } \\
\hline GDP Shares & & & \\
Primary surplus & 7,38 & 23,45 & 3,17 \\
Total surplus & 3584,15 & 46292,78 & 12,91 \\
Public Debt & 7,39 & 23,45 & 3,17 \\
\hline Real Variables & & & \\
Primary surplus & 21866,54 & 68629,64 & 3,14 \\
Total surplus & 30481,03 & 54968,44 & 1,80 \\
Public Debt & 174821,77 & 627490,78 & 3,59 \\
\hline
\end{tabular}


Table 3. Unit Root Tests for GDP shares

\begin{tabular}{|c|c|c|c|c|c|c|c|c|c|}
\hline \multirow{2}{*}{$\begin{array}{l}\text { Sample period } \\
\text { Variable }\end{array}$} & \multicolumn{3}{|c|}{$1951-2002$} & \multicolumn{3}{|c|}{$1951-1975$} & \multicolumn{3}{|c|}{ 1976-2003 } \\
\hline & $\mathrm{ADF}(4)$ & $\mathrm{PP}(12)$ & Verdict & $\operatorname{ADF}(2)$ & $\mathrm{PP}(6)$ & Verdict & $\mathrm{ADF}(2)$ & $\mathrm{PP}(6)$ & Verdict \\
\hline Public Debt & $-2.595^{* *}$ & $-2.083^{* *}$ & Unit Root & $0.125^{* *}$ & $1.570^{* *}$ & Unit Root & $-1.193^{* *}$ & $-0.623^{* *}$ & Unit Root \\
\hline Primary Surplus & $-1.969^{* *}$ & $-1.753^{* *}$ & Unit Root & $-0.566^{* *}$ & $0.860^{* *}$ & Unit Root & $-1.146^{* *}$ & $-1.186^{* *}$ & Unit Root \\
\hline Total Surplus & $-1.632^{* *}$ & $-1.105^{* *}$ & Unit Root & $0.380^{* *}$ & $1.039^{* *}$ & Unit Root & $-1.206^{* *}$ & $-1.526^{* *}$ & Unit Root \\
\hline Total Revenues & $-2.241^{* *}$ & $-1.987^{* *}$ & Unit Root & $0.323^{* *}$ & $-2.060^{* *}$ & Unit Root & $-1.039^{* *}$ & $-0.604^{* *}$ & Unit Root \\
\hline Total Outlays & $-1.932^{* *}$ & $-1.119^{* *}$ & Unit Root & $-0.924^{* *}$ & $-2.636^{* *}$ & Unit Root & $-0.811^{* *}$ & $0.610^{* *}$ & Unit Root \\
\hline Non-Interest Outlays & $-1.308^{* *}$ & $-2.026^{* *}$ & Unit Root & $-2.023^{* *}$ & $-3.450^{* *}$ & Unit Root & $-1.288^{* *}$ & $-1.573^{* *}$ & Unit Root \\
\hline Interest Outlays & $-1.943^{* *}$ & $-1.178^{* *}$ & Unit Root & $2.225^{* *}$ & $2.828^{* *}$ & Unit Root & $-0.523^{* *}$ & $-0.256^{* *}$ & Unit Root \\
\hline Critical values 1\% & -4.158 & -4.142 & & -4.158 & -4.394 & & -4.322 & -4.394 & \\
\hline Critical values $5 \%$ & -3.504 & -3.496 & & -3.659 & -3.612 & & -3.579 & -3.612 & \\
\hline
\end{tabular}

Note: ${ }^{* * *}=$ significant at $5 \% / 1 \% . \mathrm{ADF}(\mathrm{x})=$ Augmented Dickey-Fuller Test with $(\mathrm{x}) 4^{\text {th }}$ order autocorrelation. $\mathrm{PP}=\mathrm{Phillips}$-Perron test with $\mathrm{x}$-year autocorrelation window. Verdict: Unit root if ADF and PP fail to reject; stationary if ADF or PP reject. 
In Italy, all these factors underwent dramatic changes in the post-Maastricht years. As figure 4 shows, real output growth came to a substantial standstill during the 1990s, while unemployment reached a peak in the second half of the 1990s and then started to decrease for the first time after several years. Political and institutional equilibria, which had lasted more or less unchanged since the end of World War II, were upset by the combined effects of the change of the electoral system from proportional representation to majority rule and of the judicial inquiries that led to the disappearance of the old parties and to the birth of new ones; in turn, these new (or renovated) parties are slowly aggregating in two coalitions that, for the first time in the country's history, alternate in government. More recently, a series of institutional reforms has more than halved the number of spending ministers (from 25 to 10) and concentrated the government's financial choices in the hands of a "Superminister" of the Economy. Budget rules became much more stringent after the "constitutionalization" of the fiscal provisions of the Maastricht Treaty and the adoption of a budgetary reform that restricted the possibility of the legislature to amend the government proposals. On the other hand, demands for income redistribution and government spending coming from the demographic evolution of the Italian population (figure 5) have probably become more pressing, as the combined effects of a negative balance between births and deaths and the smoothing of the social impact of firms' restructuring through early retirement schemes increased the share of the population dependent on the income-producing individuals. Finally, the Maastricht Treaty itself strengthened the "external constraint" that historically has driven all the major policy choices in Italy during the last decades.

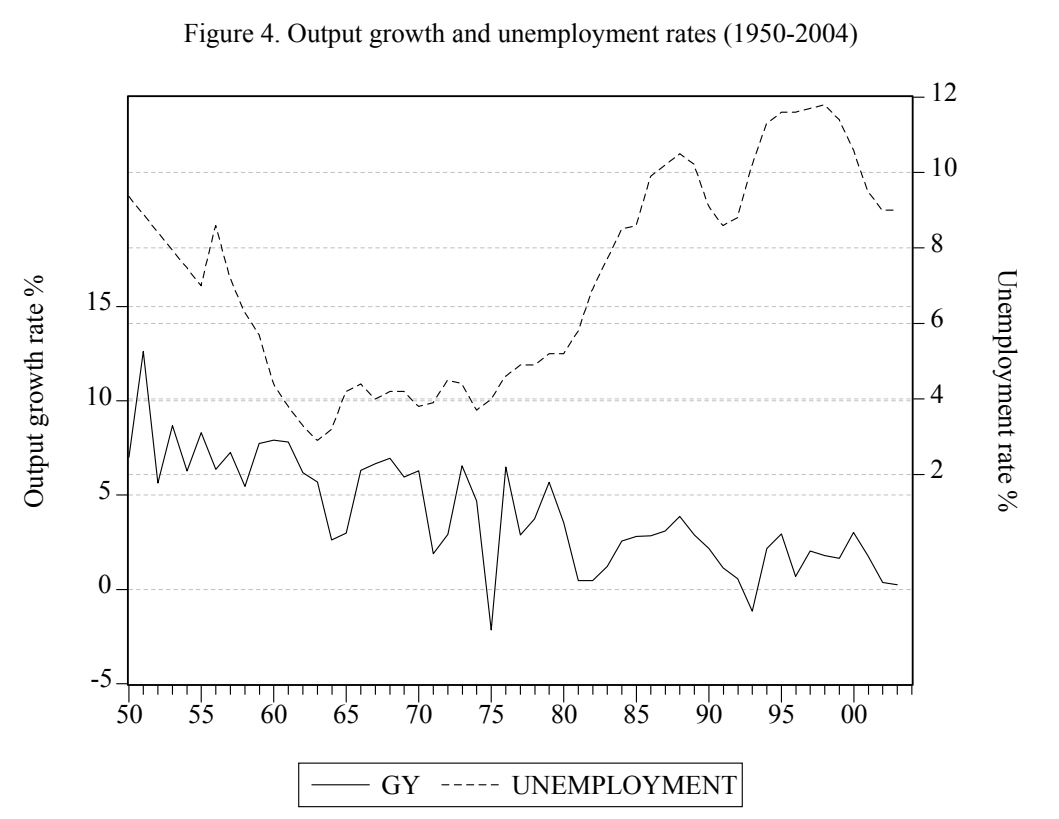


Figure 5. Percentage of population over 65 (1950-2002)

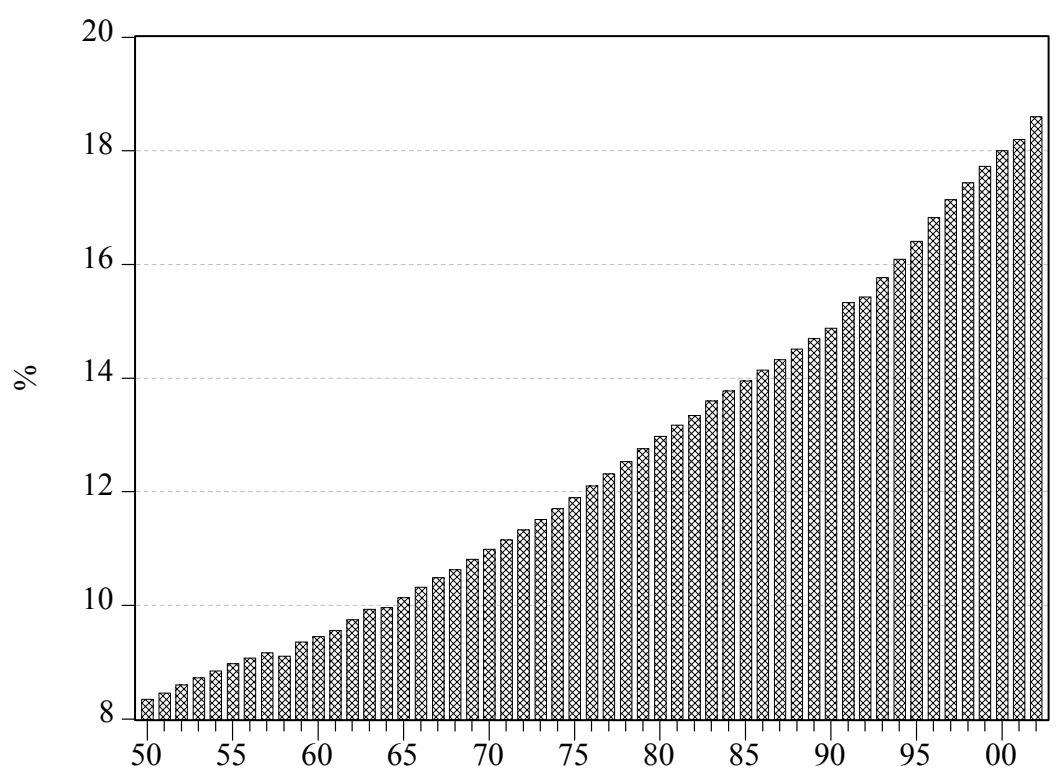

These historical developments warrant an empirical analysis "before and after" Maastricht in order to assess whether the Stability and Growth Pact affected not only the deficit levels (figure 1) but also the processes that determine the Italian fiscal choices. We thus estimate a model of the determinants of public deficits first on a sample period from 1950 to 1990, one year before the signing of the Maastricht Treaty, then on a sample period from 1950 up to 2002, the last year for which a complete data set is available. By comparing the results we aim to highlight structural changes in the processes of debt creation related to the need to converge to the Maastricht criteria.

It is important to stress that the convergence process has influenced the fiscal performance both directly, through the adoption of restrictive policies, and indirectly, e.g., by forcing the adoption of institutional reforms and by conditioning the electoral results and political equilibria, which in turn affected fiscal choices. These indirect effects require that the econometric model allow for a comprehensive consideration of the various determinants of public deficits. Hence the choice of a cointegration-vector error model, because it imposes the lightest theoretical structure on the data by letting the dynamics of the relationships, which theoretical models often leave unspecified, emerge from the stochastic properties of the data themselves. As dependent variable we choose the total, with interest public deficit over primary deficit, because the accounting definition of the primary deficit changed more frequently during the sample of interest than total deficit. In addition, we focus on deficits rather than debt, as variations of the stock of the debt derive from changes in the flux of deficits. Finally, we focus on the accounting of the general, rather than the central government, since Italy was a highly centralized state throughout the sample. 
Previous empirical analyses of the evolution of Italian public deficits can be divided in two strands. An extensive body of literature follows an historical approach based mainly on descriptive statistics. The Storia Monetaria d'Italia (Monetary History of Italy) by Fratianni and Spinelli (1991) is one of the outstanding works within this line of research; Brunila, Buti and Franco (2001) and Giudice and Montanino (2003) are recent contributions focussing on the Stability and Growth Pact. The second approach is based on econometric estimates of models of the determinants of Italian public deficits (Balassone and Giordano, 2001; Padovano and Venturi, 2001; Galli and Padovano, 2002). Balassone and Giordano (2001) find evidence that compromises between different ideological motivations within multiparty governments result in a bias toward running budget deficits, even if all parties within the coalition prefer balanced budgets. Padovano and Venturi (2001) instead show that measures of ideological polarization loose their explanatory power once estimated alongside indicators of political fragmentation of government coalitions. This leads to the conclusion that Italian parties members of government coalitions tend to behave opportunistically rather than ideologically. Finally, Galli and Padovano (2002) open the analysis to the comparison of a larger set of economic, demographic and politico-institutional theories of the determinants of Italian public deficits. In a sample that covers the 1950-1998 interval, they find that deficits are sensitive to interest groups' preferences (especially those of the elderly), government fragmentation, changes in the degree of stringency of budget rules and external economic constraints. Data instead provide a weak or no support to the hypotheses that deficits respond to output growth and electoral events. In this paper we exploit the availability of a longer time span after the Maastricht Treaty to reconsider and extend the analysis of our previous work.

\section{Short survey of the theories under investigation}

4.1. The Keynesian theory. While there is a tendency to consider Keynesian macroeconomics as a falsified and outdated theory, at least in Italy it still constitutes the cultural background of economic policymakers. Furthermore, as Buchanan and Wagner (1977) pointed out, when it did represent the scientific mainstream, Keynesianism provided the theoretical justification for debt financing. Hence, whatever its current standing in economics, Keynesian macroeconomic policy holds an explanatory potential of both past and present Italian fiscal policy choices.

Keynesian macroeconomic policy sees deficits as a tool for counter cyclical policy. The unemployment and/or the output growth rate are generally considered the relevant indicators of the state of the economy. The prediction is that budgets deficits be positively correlated with the rate of unemployment and negatively correlated with the growth rate of real output. In the analysis we choose three state variables: 1) The deviations of the unemployment rate around a time-varying 
trend, approximated as a Hodrick-Prescott filter of the annual series. This variable (labeled TRU) is consistent with the standard Keynesian-Phillips curve interpretation of unemployment, which implies that politicians respond only to its cyclical component. 2) The rate of unemployment $(U)$. This specification presupposes that policy makers try to reduce the social and political problems that high unemployment engenders, irrespective of the position of the economy through the cycle or of the structural component of $U$ overwhelming the cyclical one. 3) The growth rate of real output $(G Y)$, calculated as the first differences of the logs of real gross domestic product; a significant coefficient on this variable suggests that fiscal policy is essentially aimed to stimulate output. The presence of GDP measures among the independent variables is an additional reason to specify the dependent variable in real terms rather than in GDP ratios.

4.2. The optimal finance theory. The fundamental difference between the Keynesian and the optimal finance approach to public debt is that, in the neo-Ricardian framework, individuals do not consider government bonds as net wealth. Barro $(1974,1979)$ holds that whenever government chooses to deficit finance a given level of expenditures, individuals save the debt issues (and their rates of return) to meet the taxes levied to pay the interest and eventually retire the principal. As debt issues do not impact on aggregate consumption, deficits are no longer a useful tool to ease out of recessions. Still, deficits can be used to smooth tax rates over time, despite fluctuations in government expenditures and GDP (tax base). A constant fiscal pressure requires budget deficits when government spending is above its trend value (such as in wartimes) and budget surpluses when it is below it (such as in peacetimes). Similarly, business cycle-induced fluctuations of the tax base require deficits in downturns and surpluses in upswings to keep the tax rate and government expenditures constant. We measure deviations of public expenditures from their normal level (labeled TREXP) and of income from its normal level (labeled TRY) as the ratio of their current value and trend value at time $t$. The trend value is obtained as an Hodrick-Prescott filter of the annual series.

4.3. The special interest group explanation. A class of public choice models explains the choice of financing public expenditures through debt rather than taxation by evaluating the political influence of interest groups that stand to gain from deficit spending (Rowley, Shughart and Tollison, 1988). While some controversy exists over which group fits in this characterization, Cukierman and Meltzer (1988), Rowley, Shughart and Tollison (1988) and Goff (1993), among others, conclude that elderly people who do not leave bequests to future generations are the most obvious candidate. The political influence of this group is supposed to increase with its percentage share of total population. This "special interest group theory" predicts a positive correlation between percentage of the population represented by elderly people and deficit levels. Incidentally, these theories are 
observationally equivalent, and conceptually similar, to Tullock's (1982) "malevolent parents" explanation of debt creation. The same variable can then be used to test both theories.

4.4. Wars of attrition. A line of research (Alesina and Drazen, 1991; Kontopoulos and Perotti 1999) identifies coalition or divided governments as an explanation for the creation and persistence of fiscal disequilibria. After an exogenous fiscal shock, coalition governments tend to delay stabilization and accumulate debt because each member of the coalition seeks to transfer the political costs of the adjustment onto the others. Padovano and Venturi (2001) argue that it is important to control for the fragmentation of the opposition coalition too, as it may affect the costs for the government coalition to delay fiscal stabilization and, by that, the equilibrium deficit level. A government coalition of, say, three parties will find it easier to stabilize the budget when it has to overcome the opposition of several poorly coordinated political forces rather than a single monolithic party. Several power indices measure political fragmentation (Huber, Kocher and Sutter, 2003) but there is no clear reason to prefer one to the others. We choose the standard Herfindhal index, because it shows the higher variability when applied to Italian government data. On the other hand, measures of ideological polarization do not seem convincing; Padovano and Venturi (2001) show that the impossibility of the Communist Party and of the parties on the extreme right to go into the government (at least until the 1990s) made it rational for the other parties to behave opportunistically rather than ideologically. We measure the Herfindhal index of the parliamentary seats of the parties that did not vote against the government in the initial confidence debate and term this variable GOVFRAG. Similarly, we estimate the concentration of the opposing coalition (OPFRAG) as the Herfindhal index of the parliamentary seats of the parties that voted against the government in the initial confidence. These indices are distributed in the $(0,1]$ interval: they equal 1 when there is one single party in the coalition (minimum fragmentation), while approach 0 when the number of parties tends to infinity (maximum fragmentation). According to the logic of war of attrition models, more fragmented coalitions tend to delay stabilizations more; GOVFRAG should then be negatively related with budget deficits. Conversely, since more fragmented opposing coalitions can be more easily used to solve struggles inside the government majority, we expect a positive partial correlation between $O P F R A G$ and the dependent variable.

A variant of this model suggests that debt is created as a by product of a war of attrition (Alesina e Perotti, 1999) within the government. Finance and spending ministers hold opposite objective functions within the government and become increasingly opposed when the economy needs to be stabilized. The ratio of the spending ministers to the finance ministers (SPENDMIN) indicates the intensity of this type of war of attrition within the government. 
4.5. Political budget cycles. The rational political budget cycles literature argues that, inasmuch as it ensures a boom, an expansionary fiscal policy before the elections raises the probability for the incumbent government majority to win the elections. That because voters perceive the boom as a sign of competence and reward it accordingly (Rogoff, 1990; Alesina, Roubini and Cohen, 1997). We use a dummy variable to test the hypothesis that governments manipulate fiscal policies before the elections to maximize the probability of re-election. The standard specification in the literature (Alesina, Roubini and Cohen, 1997) is a variable (labelled ELE) which equals 1 in the election year if the elections occur in the second half of that year; 1 in the election year and in the year before the election if the polling day lies in the first half the year; and 0 in all other years. Alternatively, we construct a variable $E L C$ which takes the value of 1 in the election year if the elections occur in the first half of that year; 1 in the election year and in the year after the election if the polling day lies in the second half the year; and 0 in all other years. This variable takes into account the time interval (roughly one year) that the Italian budget rules open between the moment when funds for a given expenditure are appropriated ("bilancio di competenza") and the moment when they are actually spent ("bilancio di cassa"). The electorate is likely to respond to the appropriation of funds (first moment) but data on deficits are registered only after expenditures are made and revenues collected (second moment).

4.6. Budgetary procedures. Recent contributions to the literature on the determinants of public deficits focus their attention on the procedures that discipline the approbation of the budget bill to explain the considerable cross country differences in fiscal performances within highly interconnected and similarly developed economies (Alesina and Perotti, 1999). The general idea is that democratic institutions allow policymakers to partially internalise the political costs of their spending decisions, with consequent deficit. Different budget procedures, however, put similarly deficit-biased policymakers under different sets of constraints. Budget outcomes thus vary according to the degree of stringency of these constraints (von Hagen, 1992; von Hagen and Harden, 1996). During the sample period, Italy has reformed its budgetary rules twice. In 1978, the introduction of the Legge Finanziaria ("Financial Bill") effectively circumvented the original provision for a budget balanced on a yearly basis enshrined in article 81 of the Constitution. The law 362/1988 introduced two corrections that limit the deficit drift engendered in the Legge Finanziaria. First, it broke the set of provisions of the original Finanziaria into a plurality of financial bills to be approved in different times of the year, thereby limiting the possibilities of logrolling, and the associated tendencies towards deficit spending, that the comprehensive structure of the Finanziaria allows. Second, it imposed voting on the budget totals at the beginning of the approbation of the budget rather than at the end, as foreseen in the original Legge Finanziaria. By 
that the deficit is set at the beginning and cannot be increased by the parliamentary struggles that occur during the budget session. The literature (da Empoli, de Ioanna and Vegas, 2000) agrees to interpret the reform of 1978 as a major reduction of the degree of stringency of the Italian budget rules; the reform of 1988 is evaluated as a partial correction, which failed to fully restore the constraining power of the pre-1978 procedures. We capture the different binding forces of the Italian budget rules by means of a qualitative variable BUDRULE that takes the value of 2 between 1950 and 1977, 0 between 1978 and 1987 and 1 between 1988 and 2002.

4.7. Economic constraints. Changes in economic conditions may place more or less binding constraints on the tendency of fiscal decision makers to go into debt. We use two different regressors to control for the effects of the state of the economy on the wars of attrition: 1) the budget costs of high interest rates; 2) the external constraints imposed on discretionary fiscal policies. 1) In a high public debt country like Italy, interest rate shocks, even of relatively small magnitude, imply a significant rise in the cost of servicing the debt. It has been observed that policymakers may decide to finance this higher cost of servicing the debt through new debt, rather than taxes (Alesina, 1988). Unexpectedly high levels of interest rates should then be positively correlated with deficits. Following Alesina, Roubini and Cohen (1997), we measure the budgetary costs of higher interest rates as the debt to GDP ratio multiplied by the change in the differential between real interest rates and the output growth rates. We call this variable COSTDEBT. To avoid the risk that the debt component of this variable engenders spurious correlations with the dependent variable, we instrument COSTDEBT by its one-lagged value. 2) Multilateral exchange rate agreements may force governments to stabilize the economy to avoid the budget costs and crowding out effects of high interest rates. The provisions of the Maastricht Treaty are a case in point. We represent the effects of these external constraints on the fiscal choices of the government by means of a qualitative variable, EXTCONST. The higher is the potential of the external constraint to restrain discretion in fiscal policy, the larger the value of the variable (Obstfeld, 1997). Specifically, EXTCONST takes the value of 0 in the years when the exchange rate of the Lira is totally flexible (1972-73), 1 if the currency abides a somewhat loose exchange rate regime (like the "Snake-in-theTunnel" from 1973 to 1979), 2 if the exchange rate system has a well developed set of rules (like Bretton Woods until 1971 and the European Monetary System from 1980 to 1991) and 3 if the regime sets explicit limits to deficits and debt levels in the way towards the creation of a single currency, as in the Maastricht Treaty (from 1992 on). The expected sign on this variable is negative. 


\section{Cointegration and vector-error correction analysis}

5.1. Tests for nonstationarity. The analysis of the stochastic properties of the series allows to: a) establish whether the deficit and each explanatory variable share a long or a short run relationship; and b) identify the appropriate lag structure for each variable. This information leads to the specification of a structural model of the determinants of public deficits devoid of spurious regression problems. Table 4 reports the results of the Augmented Dickey-Fuller $(A D F)$ and Phillips-Perron $(P P)$ test of nonstationarity of the series. A significant test statistic rejects the null hypothesis of nonstationarity of the series in their levels. The test specification is with a constant, a trend and a constant or none of the two, as appropriate for each series. Finally, the test is performed for the 1950-1990 and 1950-2002 sample period to find the appropriate specification for the pre and post-Maastricht models. Nonstationarity can be rejected at the $1 \%$ level in both periods for $T R U$, $G Y, T R E X P, T R Y$, as one would expect from growth rates and series that capture deviations from a trend. Also for GOVFRAG and OPFRAG nonstationarity can be rejected, consistently with the erratic nature of Italian government coalitions. As for COSTDEBT, nonstationarity can be rejected only for the 1950-1990, while it cannot for the sample including also the Maastricht years. This is first evidence that joining the EMU stabilized both the interest rate and the output growth rate component of the variable. For all the other series - dependent variable included - the null hypothesis of nonstationarity cannot be rejected at the $1 \%$ level in either period. Though it is a war of attrition variable, SPENDMIN is much less erratic, as the number of spending ministers relatively to the finance ministers rose steadily from the 1950 s to the mid-1990s, to decrease only recently. 
Table 4. Tests of nonstationarity of the series

\begin{tabular}{|c|c|c|c|c|c|c|}
\hline \multirow{2}{*}{$\begin{array}{l}\text { Sample period } \\
\text { Variable }\end{array}$} & \multicolumn{3}{|c|}{$1950-1990$} & \multicolumn{3}{|c|}{$1950-2002$} \\
\hline & $A D F(4)$ & $\begin{array}{l}\text { Phillips } \\
\text { Perron(12) }\end{array}$ & $\begin{array}{l}\text { Test } \\
\text { specification }\end{array}$ & $A D F(4)$ & $\begin{array}{l}\text { Phillips } \\
\text { Perron (12) }\end{array}$ & $\begin{array}{l}\text { Test } \\
\text { specification }\end{array}$ \\
\hline$D E F$ & -0.099 & -0.10 & $\begin{array}{l}\text { Trend and } \\
\text { constant }\end{array}$ & -0.616 & -0.910 & None \\
\hline$d(D E F)$ & $-4.25^{* * *}$ & $-6.54^{* * *}$ & $\begin{array}{l}\text { Trend and } \\
\text { constant }\end{array}$ & $-3.695^{* * *}$ & $-8.488^{* * *}$ & None \\
\hline POP65 & -3.15 & $-3.32^{*}$ & $\begin{array}{l}\text { Trend and } \\
\text { constant }\end{array}$ & -0.518 & -0.687 & $\begin{array}{l}\text { Trend and } \\
\text { constant }\end{array}$ \\
\hline$d($ POP65) & $-4.183^{* * *}$ & $-6.08^{* * *}$ & $\begin{array}{l}\text { Trend and } \\
\text { constant }\end{array}$ & $-3.132^{*}$ & $-4.427^{* * *}$ & $\begin{array}{l}\text { Trend and } \\
\text { constant }\end{array}$ \\
\hline$U$ & -1.71 & -1.597 & None & -2.3406 & -2.283 & $\begin{array}{l}\text { Trend and } \\
\text { constant }\end{array}$ \\
\hline$d(U)$ & $-3.07^{* * *}$ & $-4.4^{* * *}$ & None & $-3.710^{* * *}$ & $-4.618^{* * *}$ & $\begin{array}{l}\text { Trend and } \\
\text { constant }\end{array}$ \\
\hline$T R U$ & $-3.403^{* * *}$ & $-3.185^{* * *}$ & None & $-4.308^{* * *}$ & $-3.344^{* * *}$ & None \\
\hline$G Y$ & $-4.759^{* * *}$ & $-6.665^{* * *}$ & $\begin{array}{l}\text { Trend and } \\
\text { constant }\end{array}$ & $-5.232^{* * *}$ & $-7.04^{* * *}$ & $\begin{array}{l}\text { Trend and } \\
\text { constant }\end{array}$ \\
\hline TREXP & $-2.924^{* * *}$ & $-2.518^{* *}$ & None & $-4.022^{* * *}$ & $-3.594^{* * *}$ & None \\
\hline$T R Y$ & $-3.682^{* * *}$ & $-3.122^{* * *}$ & None & $-4.785^{* * *}$ & $-4.009^{* * *}$ & None \\
\hline GOVFRAG & $-4.527^{* * *}$ & $-7.17^{* * *}$ & $\begin{array}{l}\text { Trend and } \\
\text { constant }\end{array}$ & $-3.910^{* *}$ & $-5.361^{*}$ & $\begin{array}{l}\text { Trend and } \\
\text { constant }\end{array}$ \\
\hline OPFRAG & $-3.12^{* * *}$ & $-4.704^{* * *}$ & $\begin{array}{l}\text { Trend and } \\
\text { constant }\end{array}$ & $-2.595^{*}$ & $-4.748^{* * *}$ & None \\
\hline$d(O P F R A G)$ & - & - & $\begin{array}{l}\text { Trend and } \\
\text { constant }\end{array}$ & $-6.915^{* * *}$ & $-12.265^{* * *}$ & None \\
\hline SPENDMIN & -2.617 & -2.458 & $\begin{array}{l}\text { Trend and } \\
\text { constant }\end{array}$ & -0.124 & -0.036 & $\begin{array}{l}\text { Trend and } \\
\text { constant }\end{array}$ \\
\hline$d(S P E N D M I N)$ & $-4.633^{* * *}$ & $-5.89^{* * *}$ & $\begin{array}{l}\text { Trend and } \\
\text { constant }\end{array}$ & $-4.879^{* * *}$ & $-7.623^{* * *}$ & $\begin{array}{l}\text { Trend and } \\
\text { constant }\end{array}$ \\
\hline COSTDEBT & $-1.728^{*}$ & $2.134^{* *}$ & None & $-2.240^{* *}$ & $-4.741^{* * *}$ & None \\
\hline$d(C O S T D E B T)$ & $-5.45^{* * *}$ & $-7.11^{* * *}$ & None & - & - & - \\
\hline
\end{tabular}

Note: ${ }^{*},{ }^{* *}$ and ${ }^{* * *}$ indicate a $10 \%, 5 \%$ and $1 \%$ significance level, respectively. The operator $d$ indicates first differences.

5.2. Tests for cointegration. Since the dependent variable is nonstationary in its levels, the next step is to test the dynamic nature of its relationship with each nonstationary independent variable: POP65, U, SPENDMIN and COSTDEBT for the 1950-1990 period and the former three for the 1950-2002 sample. Table 5 presents the results of the Johansen cointegration tests. The null hypothesis is that there is no cointegration, namely, that the two series have no equilibrium 
condition which keeps them in proportion to each other in the long run. The lag structure of the series and the assumption about the presence of an intercept and/or of a deterministic trend in the cointegrating equation are as the dynamics of the series suggest.

The likelihood ratio test statistics indicates one cointegrating equation between deficits and the size of the elderly population at the 5\% level. This result is plausible given the long run implications stemming from demographic trends. As expected, U, SPENDMIN and COSTDEBT do not result cointegrated with public deficits, consistently with the short run dynamics of the Keynesian, war of attrition and economic constraint models, respectively.

Table 5. Johansen cointegration test

\begin{tabular}{lccccc}
\hline Sample & \multicolumn{5}{c}{$1950-1990$} \\
\hline Variable & Lag structure & Eigenvalue & $\begin{array}{l}\text { Likelihood } \\
\text { Ratio }\end{array}$ & $\begin{array}{l}5 \% \text { critical } \\
\text { values }\end{array}$ & $\begin{array}{l}1 \% \text { critical } \\
\text { value }\end{array}$ \\
\hline POP65 & 1 & 0.327 & 26.323 & 25.32 & 30.45 \\
U & 1 & 0.235 & 16.677 & 25.32 & 30.45 \\
SPENDMIN & 1 & 0.291 & 20.4 & 25.32 & 30.45 \\
COSTDEBT & 1 & 0.302 & 23.819 & 25.32 & 30.45
\end{tabular}

\begin{tabular}{lccccc}
\hline Sample & \multicolumn{5}{c}{$1950-2002$} \\
Variable & Lag structure & Eigenvalue & $\begin{array}{l}\text { Likelihood } \\
\text { Ratio }\end{array}$ & $\begin{array}{l}\text { 5\% critical } \\
\text { values }\end{array}$ & $\begin{array}{l}\text { 1\% critical } \\
\text { value }\end{array}$ \\
\hline POP65 & 1 & 0.4652 & 34.016 & 19.96 & 24.6 \\
U & 1 & 0.2443 & 16.95 & 25.32 & 30.45 \\
SPENDMIN & 1 & 0.1269 & 6.976 & 18.17 & 23.46
\end{tabular}

5.3. Vector error correction. The assessment of the stochastic properties of the series and the identification of one cointegrating equation between deficits and elderly population allows us to specify and estimate a vector error correction model. We regress the first difference of the endogenous variable $D E F$ on a one period lag of the cointegrating equation and on all the other independent variables.

Table 6 reports the estimates of the vector error correction model, where the best fitting models (evaluated stepwise on the basis of the Schwarz criterion) are estimated for the 1950-90 "pre-Maastricht sample" and for the 1950-2002 "post-Maastricht sample". 
Table 6. Vector error correction estimates

\begin{tabular}{|c|c|c|c|c|}
\hline Sample & \multicolumn{2}{|c|}{$1950-1990$} & \multicolumn{2}{|c|}{$1950-2002$} \\
\hline Dependent Variable & \multicolumn{2}{|c|}{$\begin{array}{c}\text { Cointegrating Equation } \\
D E F_{t-1}\end{array}$} & \multicolumn{2}{|c|}{$\begin{array}{c}\text { Cointegrating Equation } \\
\qquad D E F_{t-1}\end{array}$} \\
\hline $\begin{array}{l}\text { Variable } \\
\text { POP65 } \\
-1\end{array}$ & $\begin{array}{r}\text { Coefficient } \\
5.92^{-06} \\
\end{array}$ & $\begin{array}{r}t \text {-stat } \\
8.44 \\
\end{array}$ & $\begin{array}{r}\text { Coefficient } \\
6.11^{-06} \\
\end{array}$ & $\begin{array}{r}t \text {-stat. } \\
5.53 \\
\end{array}$ \\
\hline Dependent Variable & \multicolumn{2}{|c|}{$\begin{array}{l}\text { Vector Error Correction } \\
\quad d\left(D E F_{t}\right)\end{array}$} & \multicolumn{2}{|c|}{$\begin{array}{c}\text { Vector Error Correction } \\
d\left(D E F_{t}\right)\end{array}$} \\
\hline Variable & Coefficient & Prob. & Coefficient & Prob. \\
\hline ECTPOP65 $5_{t-1}$ & -0.348 & 0.03 & -0.873 & 0.00 \\
\hline$T R E X P_{t}$ & 0.0003 & 0.02 & 0.0004 & 0.00 \\
\hline$T R Y_{t}$ & -0.0001 & 0.04 & -0.0001 & 0.3 \\
\hline $\mathrm{EXTCONST}_{t}$ & -0.439 & 0.8 & -4.126 & 0.05 \\
\hline$E L E_{t}$ & -1.302 & 0.5 & 3.641 & 0.4 \\
\hline$B U D R U L E_{t}$ & -13.634 & 0.00 & -16.25 & 0.00 \\
\hline SPENDMIN $_{t}$ & 0.605 & 0.00 & 0.834 & 0.00 \\
\hline$d(U)_{t}$ & -1.04 & 0.58 & -1.317 & 0.7 \\
\hline$C O S T D E B T_{t-1}$ & -173.41 & 0.00 & -142.93 & 0.00 \\
\hline Adj. $R^{2}$ & 0.44 & & 0.51 & \\
\hline S.E. of regression & 5.47 & & 14.79 & \\
\hline Log likelihood & -110.0 & & -196.5 & \\
\hline Schwarz criterion & 6.837 & & 8.737 & \\
\hline N. obs. & 40 & & 52 & \\
\hline
\end{tabular}

Note: The operator $d$ indicates first differences.

The first result that deserves attention is the coefficient on EXTCONST. While it is not significant in the 1950-90 sample, it becomes so and with the expected negative sign in the 19502002 sample. This evolution captures the direct effect of the Maastricht Treaty on the deficit. Previous exchange rate agreements were not so binding on the country fiscal choices; the "Maastricht numbers" are.

Other indirect effects of the Maastricht Treaty are captured by the evolution of the coefficients on BUDRULE and SPENDMIN. While significant and with the expected negative sign in both samples, the coefficient on BUDRULE is greater in the full sample. The reforms to the budget approbation procedures introduced after the constitutionalization of the Maastricht Treaty to further increase the constraints on policymakers' bias for deficit spending have indeed proved effective. Similarly, the greater political weight of the Minister of the Economy relative to the spending ministers ensuing the reduction of their number has a distinct impact on fiscal imbalances; the size of the coefficient on SPENDMIN increases by $25 \%$. This regressor proves multicollinear with GOVFRAG and OPFRAG, but holds a greater explanatory power than the latter two variables, 
which have therefore been excluded from the final specification of the regression model. We infer that the relevant locus of war of attritions within Italian government coalitions is the Cabinet, rather than the Parliament. The reunification of the previous three financial ministries (Treasury, Finances and Budget) into one Ministry for the Economy implies that only one party holds such a Ministry and, consequently, that the other government coalition members hold spending portfolios. Hence, the Council of Ministers is where the parties fight and find deals over fiscal choices.

Keynesian variables do not seem to play an important role, as neither the rate of growth of real output nor the various specifications of unemployment ever turn out significant. While it would be excessive to infer that Italian fiscal authorities never targeted economic growth or unemployment, they did not do so in the countercyclical manner postulated by the functional finance theory. The political conveniences of deficit spending outweighed the welfare maximization logic of Keynesian fiscal policy, in line with the arguments of Buchanan and Wagner (1977).

As for the optimal finance variables, in all regressions TREXP shows the correct sign and is strongly significant, whereas the coefficient on $T R Y$ is significant only in the pre-Maastricht sample. The large deviations from the trend of Italian public expenditures mainly depend on the large share of entitlement programs in the budget outlays. A negative fiscal shock is automatically transmitted to public expenditures and deficits must be raised to keep the fiscal pressure constant; this explains the steady significance of TREXP. Conversely, the loss of significance of TRY when the 1990-2002 years is also considered may be due to the lower distortionary effect of the Italian tax system in the 1990s with respect to the previous years, which makes the fundamental hypothesis to the Barro (1979) model less plausible in the full sample period. The 1970s and 1980s saw a dramatic increase of the deadweight costs of taxation due to reforms that raised the effective progressivity of the system and to the fiscal drag resulting from the high inflation rates; the 1990s, instead, witnessed, on the one hand, tax reforms that slowly made the rates more proportional and, on the other hand, a sharp decline of inflation with a lower fiscal drag. In this scenario, shocks to the tax base affect the excess burden of taxation less, with a lower need to intervene by issuing debt.

Elections do not seem to have a significant direct effect on the dynamics of budget deficits, in none of the sample, though the coefficient acquires the correct sign and becomes closer to being significant once the recent years, when two coalitions alternate in government, are considered. Nevertheless, the lack of explanatory power of the ELE regressor (as well as on ELC, though the results on this variable were not reported) is largely due to the fact that elections did not occur at regular, predictable intervals. This reduces the possibility to organize an expansion of the budget before, and a contraction after, the polls. 
The lagged value of COSTDEBT, which measures the budgetary cost of high interest rates, is always significant and presents the expected negative sign. The size of the coefficient is smaller for the full sample, a sign that the stabilization of the interest rate on the Italian public debt after joining the EMU made public deficits less sensitive to the financial costs of servicing the debt.

Finally, the percentage of the elderly on the total population holds the expected positive sign and is always significant. The coefficient grows in the overall sample, in line with the larger and rising share of the expenditures for pension and social security in the Italian budget. The error correction term is negative and significant and shows a faster return to normal values once the 1990s are taken into account, probably because of the effects of the pension reforms that have been introduced in 1993, 1995 and 1997.

Overall the models explain approximately 44\% (1950-90) and 51\% (1950-02) of the total variation of the dependent variable, with considerable precision

\section{Dummy variable model}

The results of the VEC models reported in Table 6 indicate that the variables that change their explanatory power the most between the "pre-Maastricht" and the "post Maastricht" sample are the binding force of the external constraints and of the budget approbation rules; the war of attrition within the cabinet; the cost of high debt levels and demands for deficit spending from the rising share of the elderly among the total population. Figure 6 reports the percentage changes of the estimated coefficients. We discard TREXP because, although significant, in the full sample TRY is not, which rejects the optimal finance theory as an explanation of the Italian public deficits. 
Figure 6. Percentage change

of the estimated coefficients

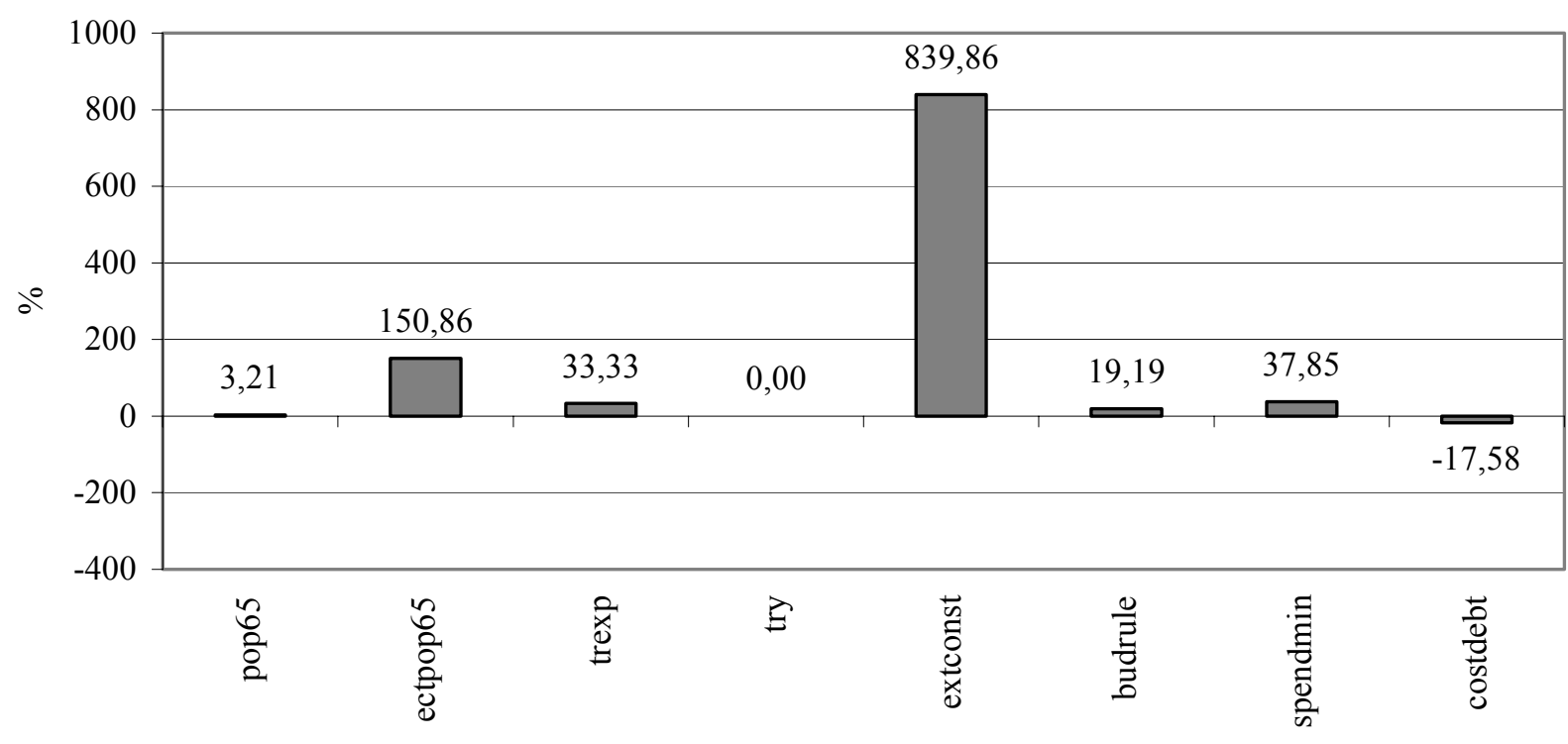

Variable

In order to assess the impact of the surviving theories on the dynamics of Italian public deficits we have estimated the following model on the entire 1950-2002 sample.

$$
\begin{aligned}
& d(D E F)_{t}=\beta_{1} E C T P O P 65_{t-1}+\beta_{2} E_{\text {XTCONST }}+\beta_{3} \text { BUDRULE }_{t}+\beta_{4} \operatorname{COSTDEBT}_{t-1}+ \\
& +\beta_{5} \operatorname{SPENDMIN}_{t}+v_{t}
\end{aligned}
$$

The advantages of this specification are twofold. First, it evaluates the impact of the structural changes, as identified in the VEC models, on the dynamics of the Italian public deficit. Second, given its more parsimonious nature, it allows decomposing the qualitative multivariate variables EXTCONST and BUDRULE into their single components by a series of dummy variables. Specifically, they are dummyBRETTONWOODS, dummySNAKETUNNEL, dummyEMS and dummyMAASTRICHT in place of EXTCONST; and dummyFINANZIARIA and dummy1988REFORM in place of BUDRULE. Each variable equals 0 in the years when the characteristic is absent and 1 in the years when it is present. Such decomposition allows to indicate which of these institutional changes most affected the dynamics of the deficit.

Table 7 reports the best estimates of equation (1), those with all the continuous variables and the dummies with significant coefficients. These are dummyMAASTRICHT and dummyFINANZIARIA, at the $5 \%$ and $1 \%$ level, respectively. Debt creation appears: a) negatively correlated with the constraint imposed by the Maastricht Treaty, which implies a downward shift of the function; $b$ ) 
positively correlated with the introduction of the Legge Finanziaria in the procedure of budget approbation that favours debt financing of public expenditures; c) positively correlated to pressures to spend in deficit coming from elderly people, though with a seemingly built in reversion to the mean; d) negatively correlated with the political power of the spending ministers with respect to the finance one(s) within the cabinet. Interestingly, other institutional factors embedded in the EXTCONST and BUDRULE multivariate variables used in the VEC models, such as the exchange rate agreements in place before Maastricht or the 1988 budgetary reform seem to carry no statistically relevant explanatory power. Moreover, Italian public deficits seem less sensitive to traditional "sustainability" criteria, such as the differential between output growth rates and interest rates.

The estimates of equation (1) suggest that prospects of (future) sustainability of Italian public finances appear mainly tied to the resilience of these institutional constraints. If the procedures to approve the budget are slackened and the Stability and Growth Pact softened, Italian deficits will soar more than in the case of an increase of the interest rates that raise expenditures for the service of the debt. Instead, if these institutional reforms are applied by a sequence of alternating coalitions and supported by the public opinion, and new reforms in this direction are introduced, Italy may slowly cease to be a financial concern for its European partners. Be that as it may, Italian deficits appear to be a case where institutions matter.

Table 6. Dummy model estimates (1950-2002)

\begin{tabular}{lcr}
\hline $\begin{array}{l}\text { Dependent Variable } \\
\text { Variable }\end{array}$ & $\begin{array}{c}\text { DEF } \\
\text { Coefficient }\end{array}$ & Prob. \\
\hline & & \\
ECTPOP65 $_{\text {t-1 }}$ & -0.613 & 0.02 \\
dummyMASTRICHT $_{t}$ & -24.041 & 0.05 \\
dummyFINANZIARIA $_{t}$ & 13.218 & 0.007 \\
COSTDEBT $_{t-1}$ & -84.878 & 0.42 \\
SPENDMIN & 0.024 & 0.06 \\
& & \\
Adj. P $^{2}$ & 0.30 & \\
S.E. of regression & 18.40 & \\
Log likelihood & -209.613 & \\
Schwarz criterion & 8.952 & \\
N. obs. & 49 & \\
\hline
\end{tabular}

\section{Conclusions}

The analysis described in this paper indicates that, while the determinants of the Italian public deficits remained by and large the same before and after Maastricht, the way in which fiscal policy reacts to each of these determinants changed considerably after the signing of the Treaty. 
Institutional constraint, be they internal, such as the budget approbation rules, or external, like the Maastricht Treaty, have always been the main condition for the Italian public finances to be in equilibrium. Our analysis further suggest that the sensitivity of Italian budget deficits to these institutional constrained increased after 1991.

These results of this analysis are quite similar, and therefore corroborate, the findings of previous analyses based on similar explanatory techniques but on a more limited time span, where the effects of the Maastricht Treaty were not completely manifest. The Maastricht years have produced a wealth of new facts to the economic, political and fiscal history of the country, but in a sense the driving forces behind Italy's public deficits remain the same. This suggests that the investigation of the determinants of the Italian public deficits is probably complete, and the potential of the explanatory approach pursued in this paper has been exhausted.

The main limit of this analytical approach is that it may explain the dynamics of fiscal totals. Yet, as budget deficits are the difference between total expenditures and total revenues, and these two totals often result from a bottom-up processes of aggregation of single expenditures programs and tax instruments, we believe that progresses in the explanation (and control) of the dynamics of the fiscal performance of a country will come from the investigation of the determinants of the composition of public expenditures and of taxation, i.e., from more disaggregated analyses based on models of the political economy of public spending and of taxation.

\section{References}

Alesina, A. (1988). The End of Large Public Debts. In F. Giavazzi and L. Spaventa (Eds). High Public Debt: the Italian Experience, 34-79, Cambridge, Cambridge University Press.

Alesina, A. and Drazen, A. (1991). Why Are Stabilizations Delayed?, American Economic Review 81: 1170-1188.

Alesina, A. and Perotti, R. (1999). Budget Deficits and Budget Institutions. In J. M. Poterba and J. von Hagen. Fiscal Institutions and Fiscal Performance. Chicago: The University of Chicago Press.

Alesina, A., Roubini, N. and Cohen, G.D. (1997). Political Cycles and the Macroeconomy. Cambridge: The MIT Press.

Balassone, F. and Giordano, R. (2001). Budget Deficits and Coalition Governments. Public Choice 106: 327-349.

Barro, R. J. (1974). Are Government Bonds Net Wealth? Journal of Political Economy 82: 1095-1117. 
Barro, R. J. (1979). On the Determination of the Public Debt. Journal of Political Economy 87: 941-971.

Bohn, H. (2004). The Sustainability of Fiscal Policy in the United States, unpublished manuscript.

Brunila, A., Buti, M. and Franco, D. (eds.) (2001). The Stability and Growth Pact. The Architecture of Fiscal Policy in EMU. Basinstoke, Palgrave.

Buchanan, J.M., and Wagner, R.E. (1977). Democracy in Deficit. New York, Academic Press.

Camera dei Deputati della Repubblica Italiana (2001). Notiziario della Camera dei Deputati. Compendio Statistico dalla I alla XIII ${ }^{a}$ Legislatura. Dati Statistici e Quantitativi. Roma: Camera dei Deputati della Repubblica Italiana.

Cukierman, A. and Meltzer A. H. (1989). A Political Theory of Government Debt and Deficits in a NeoRicardian Framework. American Economic Review 79: 713-732.

da Empoli, D., De Ioanna, P. and Vegas G. (2000). Il bilancio dello Stato. La Finanza Pubblica tra Governo e Parlamento. Milano, Ed. Il Sole-24 Ore.

Fratianni, M. and Spinelli, F. (1991). La Storia Monetaria d'Italia: 1860 - 1980. Milan, Mondadori.

von Hagen, J. (1992). Budgeting Procedures and Fiscal Performance in the European Community. Commission of the European Communities, Economic Paper n. 96.

von Hagen, J. and Harden, J. (1994). Budget Processes and Commitment to Fiscal Discipline. European Economic Review 39: 771-779.

Galli, E., and Padovano, F. (2002). A Comparative Test of Alternative Theories of the Determinants of Public Deficits. Public Choice, 113: pp. 37-58

Giudice, G. and Montanino, A. (2003). Il Patto di Stabilità e Crescita. Rivista di Politica Economica Luglio-Agosto. 185-273.

Goff, B. L. (1993). Evaluating Alternative Explanations of Postwar Federal Deficits, Public Choice 75: 247-261.

Huber, G., Kocher, M. and Sutter, M. (2003). Government Strength, Power Dispersion in Governments and Budget Deficits in OECD-Countries. A Voting Power Approach. Public Choice 116: 333-350.

Kontopoulos, J. and Perotti, R. (1999). Government Fragmentation and Fiscal Policy Outcomes. In J.M. Poterba and J. Von Hagen (Eds.) Fiscal Institutions and Fiscal Performance, 81-102. Chicago: The University of Chicago Press.

IMF (various years). Government Financial Statistics. Washington D.C.: IMF. 
ISTAT (various issues). Annuario Statistico Italiano. Roma: ISTAT.

Obstfeld, M. (1997). Destabilizing Effects of Exchange Rate Escape Clauses. Journal of International Economics 43: 61-77.

OECD (various years), Economic Outlook, Paris: OECD.

OECD (various years), Historical Statistics, Paris: OECD.

Padovano, F. and Venturi, L. (2001). Wars of Attrition in Government Coalitions and Fiscal Performance: A Test on Italian 1948-1994 Data. Public Choice 109: 15-54

Rogoff, K. (1990). Political Budget Cycles. American Economic Review 80: 1-16.

Roubini, N. and Sachs, J. (1989). Government Spending and Budget Deficits in the Industrialized Countries. Economic Policy 8: 700-732.

Rowley, C. K., Shughart, W. F. and Tollison, R. D. (1988). Interest Groups and Deficits. In J. M. Buchanan, C. K. Rowley and R. D. Tollison (eds), Deficits, 263-280. London: Basic Blackwell.

Senato della Repubblica Italiana (various years). Atti Parlamentari. Roma: Senato della Repubblica Italiana.

Trehan, B. and Walsh, C. (1988). Common Trends, the Government Budget Constraint and Revenue Smoothing, Journal of Economic Dynamics and Control 12: 425-444.

Trehan, B. and Walsh, C. (1988). Testing Intertemporal Budget Constraints: Theory and Applications to U.S. Federal Budget and Current Accounts Deficits, Journal of Money, Credit and Banking 23: 210-223.

Tullock, G. (1982). The Economics of Income Redistribution. Boston, Kluwer-Nijhoff.

Woldendorp, J., Keman, H. and Budge, I. (1993). Political Data 1945-1990. Party Government in 20 Democracies. European Journal of Political Research, 24: 1-119.

Woldendorp, J., Keman, H. and Budge, I. (1998). Party Government in 20 Democracies: An Update (1990-1995). European Journal of Political Research, 33: 1-119. 


\title{
CESifo Working Paper Series
}

\author{
(for full list see www.cesifo.de)
}

1329 Chiona Balfoussia and Mike Wickens, Macroeconomic Sources of Risk in the Term Structure, November 2004

1330 Ludger Wößmann, The Effect Heterogeneity of Central Exams: Evidence from TIMSS, TIMSS-Repeat and PISA, November 2004

1331 M. Hashem Pesaran, Estimation and Inference in Large Heterogeneous Panels with a Multifactor Error Structure, November 2004

1332 Maarten C. W. Janssen, José Luis Moraga-González and Matthijs R. Wildenbeest, A Note on Costly Sequential Search and Oligopoly Pricing, November 2004

1333 Martin Peitz and Patrick Waelbroeck, An Economist's Guide to Digital Music, November 2004

1335 Lutz Hendricks, Why Does Educational Attainment Differ Across U.S. States?, November 2004

1336 Jay Pil Choi, Antitrust Analysis of Tying Arrangements, November 2004

1337 Rafael Lalive, Jan C. van Ours and Josef Zweimueller, How Changes in Financial Incentives Affect the Duration of Unemployment, November 2004

1338 Robert Woods, Fiscal Stabilisation and EMU, November 2004

1339 Rainald Borck and Matthias Wrede, Political Economy of Commuting Subsidies, November 2004

1340 Marcel Gérard, Combining Dutch Presumptive Capital Income Tax and US Qualified Intermediaries to Set Forth a New System of International Savings Taxation, November 2004

1341 Bruno S. Frey, Simon Luechinger and Alois Stutzer, Calculating Tragedy: Assessing the Costs of Terrorism, November 2004

1342 Johannes Becker and Clemens Fuest, A Backward Looking Measure of the Effective Marginal Tax Burden on Investment, November 2004

1343 Heikki Kauppi, Erkki Koskela and Rune Stenbacka, Equilibrium Unemployment and Capital Intensity Under Product and Labor Market Imperfections, November 2004

1344 Helge Berger and Till Müller, How Should Large and Small Countries Be Represented in a Currency Union?, November 2004

1345 Bruno Jullien, Two-Sided Markets and Electronic Intermediaries, November 2004 
1346 Wolfgang Eggert and Martin Kolmar, Contests with Size Effects, December 2004

1347 Stefan Napel and Mika Widgrén, The Inter-Institutional Distribution of Power in EU Codecision, December 2004

1348 Yin-Wong Cheung and Ulf G. Erlandsson, Exchange Rates and Markov Switching Dynamics, December 2004

1349 Hartmut Egger and Peter Egger, Outsourcing and Trade in a Spatial World, December 2004

1350 Paul Belleflamme and Pierre M. Picard, Piracy and Competition, December 2004

1351 Jon Strand, Public-Good Valuation and Intrafamily Allocation, December 2004

1352 Michael Berlemann, Marcus Dittrich and Gunther Markwardt, The Value of NonBinding Announcements in Public Goods Experiments: Some Theory and Experimental Evidence, December 2004

1353 Camille Cornand and Frank Heinemann, Optimal Degree of Public Information Dissemination, December 2004

1354 Matteo Governatori and Sylvester Eijffinger, Fiscal and Monetary Interaction: The Role of Asymmetries of the Stability and Growth Pact in EMU, December 2004

1355 Fred Ramb and Alfons J. Weichenrieder, Taxes and the Financial Structure of German Inward FDI, December 2004

1356 José Luis Moraga-González and Jean-Marie Viaene, Dumping in Developing and Transition Economies, December 2004

1357 Peter Friedrich, Anita Kaltschütz and Chang Woon Nam, Significance and Determination of Fees for Municipal Finance, December 2004

1358 M. Hashem Pesaran and Paolo Zaffaroni, Model Averaging and Value-at-Risk Based Evaluation of Large Multi Asset Volatility Models for Risk Management, December 2004

1359 Fwu-Ranq Chang, Optimal Growth and Impatience: A Phase Diagram Analysis, December 2004

1360 Elise S. Brezis and François Crouzet, The Role of Higher Education Institutions: Recruitment of Elites and Economic Growth, December 2004

1361 B. Gabriela Mundaca and Jon Strand, A Risk Allocation Approach to Optimal Exchange Rate Policy, December 2004

1362 Christa Hainz, Quality of Institutions, Credit Markets and Bankruptcy, December 2004 
1363 Jerome L. Stein, Optimal Debt and Equilibrium Exchange Rates in a Stochastic Environment: an Overview, December 2004

1364 Frank Heinemann, Rosemarie Nagel and Peter Ockenfels, Measuring Strategic Uncertainty in Coordination Games, December 2004

1365 José Luis Moraga-González and Jean-Marie Viaene, Anti-Dumping, Intra-Industry Trade and Quality Reversals, December 2004

1366 Harry Grubert, Tax Credits, Source Rules, Trade and Electronic Commerce: Behavioral Margins and the Design of International Tax Systems, December 2004

1367 Hans-Werner Sinn, EU Enlargement, Migration and the New Constitution, December 2004

1368 Josef Falkinger, Noncooperative Support of Public Norm Enforcement in Large Societies, December 2004

1369 Panu Poutvaara, Public Education in an Integrated Europe: Studying to Migrate and Teaching to Stay?, December 2004

1370 András Simonovits, Designing Benefit Rules for Flexible Retirement with or without Redistribution, December 2004

1371 Antonis Adam, Macroeconomic Effects of Social Security Privatization in a Small Unionized Economy, December 2004

1372 Andrew Hughes Hallett, Post-Thatcher Fiscal Strategies in the U.K.: An Interpretation, December 2004

1373 Hendrik Hakenes and Martin Peitz, Umbrella Branding and the Provision of Quality, December 2004

1374 Sascha O. Becker, Karolina Ekholm, Robert Jäckle and Marc-Andreas Mündler, Location Choice and Employment Decisions: A Comparison of German and Swedish Multinationals, January 2005

1375 Christian Gollier, The Consumption-Based Determinants of the Term Structure of Discount Rates, January 2005

1376 Giovanni Di Bartolomeo, Jacob Engwerda, Joseph Plasmans, Bas van Aarle and Tomasz Michalak, Macroeconomic Stabilization Policies in the EMU: Spillovers, Asymmetries, and Institutions, January 2005

1377 Luis H. R. Alvarez and Erkki Koskela, Progressive Taxation and Irreversible Investment under Uncertainty, January 2005

1378 Theodore C. Bergstrom and John L. Hartman, Demographics and the Political Sustainability of Pay-as-you-go Social Security, January 2005 
1379 Bruno S. Frey and Margit Osterloh, Yes, Managers Should Be Paid Like Bureaucrats, January 2005

1380 Oliver Hülsewig, Eric Mayer and Timo Wollmershäuser, Bank Loan Supply and Monetary Policy Transmission in Germany: An Assessment Based on Matching Impulse Responses, January 2005

1381 Alessandro Balestrino and Umberto Galmarini, On the Redistributive Properties of Presumptive Taxation, January 2005

1382 Christian Gollier, Optimal Illusions and Decisions under Risk, January 2005

1383 Daniel Mejía and Marc St-Pierre, Unequal Opportunities and Human Capital Formation, January 2005

1384 Luis H. R. Alvarez and Erkki Koskela, Optimal Harvesting under Resource Stock and Price Uncertainty, January 2005

1385 Ruslan Lukach, Peter M. Kort and Joseph Plasmans, Optimal R\&D Investment Strategies with Quantity Competition under the Threat of Superior Entry, January 2005

1386 Alfred Greiner, Uwe Koeller and Willi Semmler, Testing Sustainability of German Fiscal Policy. Evidence for the Period 1960 - 2003, January 2005

1387 Gebhard Kirchgässner and Tobias Schulz, Expected Closeness or Mobilisation: Why Do Voters Go to the Polls? Empirical Results for Switzerland, 1981 - 1999, January 2005

1388 Emanuele Bacchiocchi and Alessandro Missale, Managing Debt Stability, January 2005

1389 Assar Lindbeck and Dirk Niepelt, Improving the SGP: Taxes and Delegation rather than Fines, January 2005

1390 James J. Heckman and Dimitriy V. Masterov, Skill Policies for Scotland, January 2005

1391 Emma Galli \& Fabio Padovano, Sustainability and Determinants of Italian Public Deficits before and after Maastricht, January 2005 